\title{
Assessment of Genetic Variability, Heritability and Genetic Advance for Yield and Quality Traits in Indica Tropical Japonica Derived Lines
}

\author{
${ }^{1}$ Crop Improvement Section, ICAR-Indian Institute of Rice Research, Hyderabad, India \\ ${ }^{2}$ College of Agriculture, Professor Jayashankar Telangana State Agricultural University \\ (PJTSAU), Hyderabad, India \\ ${ }^{3}$ National Academy of Agricultural Research Management (NAARM), Hyderabad, India
}

*Corresponding author

\section{Keywords}

Genetic variability, Heritability and Genetic advance, Yield, Indica

Article Info

Accepted:

22 March 2020

Available Online:

10 April 2020

\section{A B S T R A C T}

The present study was carried out to estimate genetic variability, heritability and genetic advance for 14 yield and yield related traits and 6 grain quality traits in 150 genotypes. The results showed that ANOVA for all the 20 traits under study revealed highly significant differences this indicates that a wide range of variability was present among 150 genotypes. Genetic variability analysis has shown that the variability for the traits namely filled grains, unfilled grains, single plant yield, per day productivity, gel consistency and alkali spreading value was high, for plant height, harvest index and amylose content variability was moderate and low variability was observed for days to $50 \%$ flowering, days to maturity, panicle length and kernel length for the material under study. High correspondence between phenotypic and genotypic variance was observed for plant height, panicle length, thousand grain weight, amylose content, gel consistency, alkali spreading value and kernel length. The high environmental influence was observed for days to $50 \%$ flowering, days to maturity, spikelet fertility, productive tillers and total number of tillers.

\section{Introduction}

Globally 723.15 million tonnes of paddy was harvested from 160.45 million hectares with average productivity of 4.51 tonnes per hectare (World Rice Statistics, 2018). India is the world's second top rice producer after China with a production of 109 million tonnes (Milled rice) in an area of 43.5 million hectares and with a productivity of 3.76tonnes 
per hectare (World Rice Statistics, 2018). By 2030 world food grain production must increase by 40 percent (FAO, 2009) to feed ever increasing population. Because of urbanization and climate change, the area under rice is decreasing over the years. To keep up with the demand, rice production frontier must be shifted by adopting novel strategies to increase the yield potential of rice with the limited available land. Yield ceiling was observed in indica rice breeding programs since the release of IR8 (Peng et al., 2003). Inter subspecific hybridization is an important strategy to break the yield barrier in rice. In the present study indica tropical japonica derived lines were evaluated for genetic variability parameters, heritability and genetic advance.

Phenotypic expression of given trait depends on genetic composition (genes), the environment in which the genotype was grown and the interaction between genes and environment. Always breeder aims for selecting phenotype stem/derived from heritable genetic effects. Genetic variance which includes both heritable and nonheritable components. Heritable variation that is due to additive genetic variance and nonheritable variation is due to dominance and epistatic variances. Only additive genetic variance will pass on to progeny from their parents (Hill et al., 2008). Hence additive genetic variance is important for selections in breeding programmes as response to selection depends on additive genetic variance. Choice of germplasm or selection of a parental line with wide and useful genetic variation is the very important step that breeder takes. The major goal of a breeder is to select the genotype with a high mean and genetic variance which ensures the better chances of producing the desired genotype. The nature and magnitude of variability is the prerequisite for breeding high yielding varieties in crops. To exploit the potentiality of the genotypes breeder should understand the basic information about nature and extent of genetic variability, heritability and genetic advance of the characters among genotypes in which heritability and genetic advance are important selection parameters to improve selection response. With this view, the present investigation was carried out to study genetic variability, heritability and genetic advance for 20 traits among 150 genotypes.

\section{Materials and Methods}

The present experiment was conducted at research farm, ICAR-IIRR, Rajendranagar, Hyderabad using alpha lattice design with three replications during Kharif 2018. Plant material consisting of 150 genotypes which include 106 indica tropical japonica derived lines, 16 female parents and 18 male parents of derived lines along with 10 checks of different durations. Each entry was planted in a single row of $4 \mathrm{~m}$ length with a spacing of $15 \times 15 \mathrm{~cm}$ and all the recommended package of practices were followed to raise a healthy crop. Yield and yield attributing traits were recorded on five plants per genotype in each replication according to the descriptors prescribed by International Rice Research Institute (SES, IRRI, 2013). The traits namely, days to $50 \%$ flowering, days to maturity, plant height $(\mathrm{cm})$, panicle length (cm), number of productive tillers, total number of tillers, number of filled grains, number of unfilled grains, spikelet fertility (\%), 1000 grain weight (g), single plant yield $(\mathrm{g})$, biomass $(\mathrm{g})$, harvest index and per day productivity $\left(\mathrm{kg} \mathrm{ha}^{-1}\right)$ were recorded. Grain quality traits, amylose content (\%), gel consistency $(\mathrm{mm})$, alkali spreading value, kernel length $(\mathrm{mm})$, kernel breadth $(\mathrm{mm})$ and kernel L/B ratio were recorded. The ANOVA and ls means were calculated using car and ls means package R studio (R Core Team, 2012) respectively and genetic variability, heritability and genetic advance were 
analyzed using Microsoft excel 2010.The genotypic coefficient of variation-GCV (Burton, 1952), phenotypic coefficient of variation-PCV (Burton, 1952), Heritability in broad sense (Lush, 1940) and genetic advance (Johnson et al., 1955) were calculated by the given standard formulae.

\section{Results and Discussion}

Analysis of variance revealed the presence of significant differences among means of 150 genotypes for all the 20 traits under study. Analysis of variance for 20 traits using alpha lattice design mentioned in table 1 . This indicating the presence of a considerable amount of genetic variance among 150 genotypes for different yield and grain quality traits. This experimental material would serve as valuable breeding material for future breeding programs as it harbors considerable amount of genetic variability. ANOVA partitions the variances for heritability estimates.

Genetic variability estimates phenotypic coefficient of variation, genotypic coefficient of variation, heritability and genetic advance as percent of mean are presented in Table 2 and Figure 1 and 2. Among 19 traits studied in the present investigation, filled grains (GCV-21.41; PCV-29.32), unfilled grains (GCV-48.11; PCV-65.23), single plant yield (GCV-27.63; PCV-36.24), per day productivity (GCV-27.25; PCV-36.23), gel consistency (GCV-21.41; PCV-29.32) and alkali spreading value (GCV-24.69; PCV24.91), exhibited high phenotypic and genotypic coefficient of variation. This was indicating that for these traits variability among 150 genotypes was high. Plant height (GCV-11.63; PCV-12.39), thousand grain weight (GCV-16.68; PCV-19.12), harvest index (GCV-11.22; PCV-19.61) and amylose content (GCV-10.25; PCV-10.41) recorded moderate phenotypic and genotypic coefficient of variation and hence moderate variability existed for these traits. Days to 50 \% flowering (GCV-4.86; PCV-8.69), days to maturity (GCV-3.69; PCV-6.63), panicle length (GCV-6.97; PCV-8.69) and kernel length (GCV-9.36; PCV-9.83) were observed with low phenotypic and genotypic coefficient of variation, which indicates low variability of these traits among 150 genotypes. Present results were in accordance with Saha et al., (2019) for number of filled grains, unfilled grains and single plant yield, Sandeep et al., (2018) and Danwani et al., (2013) for single plant yield and Danwani et al., (2013) for gel consistency, Sandeep et al., (2018), Govindaraj et al., (2018) and Abebe et al., (2017) for plant height, Abebe et al., (2017) and Durai et al., (2014) for harvest index, Sahu et al., (2017) for amylose content, Asante et al., (2019), Tiwari et al., (2019) and Manjunatha et al., (2017) for days to $50 \%$ flowering, Tiwari et al., (2019) and Saha et al., (2019) for days to maturity, Saha et al., (2019) and Govindaraj et al., (2018) for panicle length, Durai et al., (2014) and Babu et al., (2012) for kernel length. Slight difference between PCV and GCV values was observed for plant height, panicle length and thousand grain weight and for all grain quality traits especially for amylose content, gel consistency, alkali spreading value and kernel length almost equal values were observed. This specifying that phenotypic expression of these traits was under genetic control.

Breeder success depends on degree of correspondence between phenotypic and genotypic values as selection is based on phenotypic performance of a particular line. Heritability estimate which provides information about the correspondence between genotypic and phenotypic variance. Hence heritability is an important selection parameter that breeder must consider while selection of a particular trait of interest. Among 20 traits, plant height (88.01\%), 
panicle length (64.65), thousand grain weight (76.23\%), amylose content (97.42\%), gel consistency $(96.34 \%)$, alkali spreading value $(98.26 \%)$ and kernel length $(91.30 \%)$ were found to be observed with high heritability. Which indicates high correspondence between phenotypic and genotypic variance and environmental influence was very less on these traits. Days to $50 \%$ flowering $(31.34 \%)$ days to maturity (30.93\%), number of filled grains $(53.26 \%)$, number of unfilled grains $(54.42 \%)$, spikelet fertility (37.56\%), single plant yield $(58.15 \%)$, biomass $(47.30 \%)$, harvest index $(32.75 \%)$, per day productivity (56.59\%), kernel breadth $(57.14 \%)$ and kernel $\mathrm{L} / \mathrm{B}$ ratio $(53.54 \%)$ were observed with moderate heritability this indicates presence of moderate environmental influence on these traits. Productive tillers $(23.29 \%)$ and total number of tillers $(22.74 \%)$ were observed with low heritability. In this case environmental influence was considered as a major factor responsible for the phenotypic expression of these two traits. Earlier research studies by Asante et al., (2019) and Saha et al., (2019) for plant height, Babu et al., (2012) for plant height and panicle length, Saha et al., (2019) and Singh and Verma, 2018 for panicle length, Asante et al., (2019) and Thippeswamy et al., (2016) for productive tillers, Tiwari et al., (2019) for total number of tillers, Sandeep et al., (2018) and Gokulakrishnan et al., (2014) for thousand grain weight, Abebe et al., (2017) for days to $50 \%$ flowering, day to maturity and harvest index, Sahu et al., (2017) for amylose content, gel consistency and kernel length. Contrary to the above results were reported by Sandeep et al., (2018) for productive tillers, spikelet fertility and grain yield, Singh and Verma (2018) for grain yield and Saha et al., (2019) for productive tillers. The heritability changes according to the type of gene action, environment and also varies from one population to another for a given trait and hence heritability estimates cannot be extrapolated from one population to other and one environment to the other. This may be the reason for contradictory results reported by several researchers. Heritability estimates must made from data collected from multiple years and locations otherwise bias may arise as quantitative traits majorly influenced by environment and in single environment the genotype and environment interaction will become negligible. It was reported that quantitative traits for example grain yield is always having low heritability because of major environmental influence.

The main purpose of estimating genetic parameters and heritability is to predict genetic gain from selection. Genetic advance under selection is defined as improvement in the mean genotypic value of the selected families over that of the base population. Genetic advance depends on phenotypic variability, heritability of the trait and intensity of selection. Utility of heritability estimates increases when used in conjunction with selection differential (Jhonson et al., 1955). Genetic advance indicates amount of genetic progress that would result from selecting best genotype. Highest genetic advance as percent of mean was recorded by gel consistency followed by alkali spreading value, unfilled grains and single plant yield. Least recorded by days to maturity followed by days to $50 \%$ flowering. According to Johnson et al., 1955, heritability estimates along with genetic advance are more helpful in predicting the gain under selection. Among 20 traits, plant height, thousand grain weight, amylose content, gel consistency and alkali spreading value expressed high broad sense heritability coupled with high genetic advance, which indicating the preponderance of additive type of gene action on expression of these traits. Hence direct selection of such traits would be effective to improve the grain yield. 
Table.1 Analysis of variance (Mean squares) for grain yield and yield attributing traits

\begin{tabular}{|c|c|c|c|c|c|c|c|c|c|c|c|c|c|}
\hline $\begin{array}{l}\text { Source of } \\
\text { Variation }\end{array}$ & d.f. & $\begin{array}{c}\text { Days to } \\
50 \\
\text { percent } \\
\text { flowering }\end{array}$ & $\begin{array}{l}\text { Days to } \\
\text { maturity }\end{array}$ & $\begin{array}{c}\text { Plant } \\
\text { height } \\
\text { (cm) }\end{array}$ & $\begin{array}{c}\text { Panicle } \\
\text { length } \\
\text { (cm) }\end{array}$ & $\begin{array}{l}\text { Productive } \\
\text { tillers plant-1 }\end{array}$ & $\begin{array}{c}\text { Total } \\
\text { number } \\
\text { of tillers }\end{array}$ & $\begin{array}{l}\text { Filled } \\
\text { grains }\end{array}$ & $\begin{array}{l}\text { Unfilled } \\
\text { grains }\end{array}$ & $\begin{array}{c}\text { Spikelet } \\
\text { fertility } \\
(\%)\end{array}$ & $\begin{array}{l}\text { Thousand } \\
\text { grain } \\
\text { weight (g) }\end{array}$ & $\begin{array}{l}\text { Single plant } \\
\text { yield (g) }\end{array}$ & $\begin{array}{c}\text { Biomass } \\
\text { (g) }\end{array}$ \\
\hline Replications & 2 & 44.95 & 44.8 & 28 & 0.93 & 2.93 & 6.49 & 1150 & $1102.5^{*}$ & 82.3 & 10.4 & 1.7 & $71.9 *$ \\
\hline $\begin{array}{l}\text { Blocks within } \\
\text { replications }\end{array}$ & 42 & 51.45 & 51.27 & 15.16 & 1.606 & 3.035 & 3.15 & 796.47 & 326.97 & $86.79 *$ & 4.82 & 6.82 & 30.65 \\
\hline Treatments & 149 & $115.87 * *$ & $114.96 * *$ & $463.47 * *$ & $9.34 * *$ & $4.33 * *$ & $5.14 * *$ & $\begin{array}{c}3734.8 \\
* *\end{array}$ & $\begin{array}{c}1088.61 * \\
*\end{array}$ & $151.13 * *$ & $45.89 * *$ & $35.76 * *$ & $79.1 * *$ \\
\hline Error & 256 & 48.91 & 49.05 & 20.14 & 1.44 & 2.26 & 2.73 & 844.65 & 237.6 & 53.88 & 4.32 & 6.92 & 21.42 \\
\hline Total & 449 & & & & & & & & & & & & \\
\hline
\end{tabular}

- $\quad *$ Significance at $5 \%$ level, ** significance at $1 \%$ level.

\begin{tabular}{|c|c|c|c|c|c|c|c|c|c|}
\hline Source of Variation & d.f. & $\begin{array}{c}\text { Harvest } \\
\text { index } \\
(\%)\end{array}$ & $\begin{array}{c}\text { Per day } \\
\text { productivity } \\
\left(\mathrm{kg} \mathrm{ha}^{-1)}\right.\end{array}$ & $\begin{array}{c}\text { Amylose } \\
\text { content } \\
(\%)\end{array}$ & $\begin{array}{c}\text { Gel } \\
\text { consistency } \\
(\mathbf{m m})\end{array}$ & $\begin{array}{c}\text { Alkali } \\
\text { spreading } \\
\text { value }\end{array}$ & $\begin{array}{l}\text { Kernel } \\
\text { length } \\
(\mathrm{mm})\end{array}$ & $\begin{array}{c}\text { Kernel } \\
\text { breadth } \\
(\mathrm{mm})\end{array}$ & $\begin{array}{c}\text { Length/breadth } \\
\text { ratio }\end{array}$ \\
\hline Replications & 2 & 131.9 & 15.5 & 0.08 & 9.5 & 0.033 & 0.035 & 0.093 & 0.058 \\
\hline $\begin{array}{l}\text { Blocks within } \\
\text { replications }\end{array}$ & 42 & 49.90 & 46.31 & 0.16 & 6.19 & 0.03 & 0.023 & $0.019 *$ & 0.034 \\
\hline Treatments & 149 & $143.14 * *$ & $214.21 * *$ & $18.86 * *$ & $647.89 * *$ & $4.60 * *$ & $0.78 * *$ & $0.14 * *$ & $0.205^{* *}$ \\
\hline Error & 256 & 58.16 & 43.62 & 0.165 & 8.1 & 0.027 & 0.024 & 0.028 & 0.046 \\
\hline Total & 449 & & & & & & & & \\
\hline
\end{tabular}

- $\quad *$ Significance at $5 \%$ level, $* *$ significance at $1 \%$ level. 
Table.2 Estimation of genetic variability parameters - mean, standard error, range, variances, coefficient of variations, broad sense heritability, genetic advance, genetic advance as percent of mean of 20 traits of 150 genotypes evaluated during Kharif 2018

\begin{tabular}{|c|c|c|c|c|c|c|c|c|c|}
\hline Characters & Mean \pm SE & Minimum & Maximum & $\begin{array}{c}\text { Genotypic } \\
\text { coefficient of } \\
\text { variation }(\%)\end{array}$ & $\begin{array}{c}\text { Phenotypic } \\
\text { coefficient of } \\
\text { variation (\%) }\end{array}$ & $\begin{array}{c}\text { Environmental } \\
\text { coefficient of } \\
\text { variation }(\%)\end{array}$ & $\begin{array}{c}\text { Broad sense } \\
\text { heritability } \\
(\%)\left(h^{2} b\right)\end{array}$ & $\begin{array}{c}\text { Genetic } \\
\text { advance } \\
(\%)\end{array}$ & $\begin{array}{c}\text { Genetic } \\
\text { advance as } \\
\text { percent of } \\
\text { mean }\end{array}$ \\
\hline Days to $50 \%$ flowering & $97.12 \pm 0.51$ & 86.00 & 116.00 & 4.86 & 8.69 & 7.20 & 31.34 & 5.45 & 5.61 \\
\hline Days to maturity & $127.1 \pm 0.51$ & 137.00 & 167.00 & 3.69 & 6.63 & 5.51 & 30.93 & 5.37 & 4.23 \\
\hline Plant height & $104.57 \pm 1.06$ & 72.00 & 152.73 & 11.63 & 12.39 & 4.29 & 88.01 & 23.49 & 22.47 \\
\hline Panicle length & $23.23 \pm 0.16$ & 17.70 & 28.10 & 6.97 & 8.69 & 5.17 & 64.65 & 2.69 & 11.57 \\
\hline Productive tillers & $6.61 \pm 0.10$ & 3.05 & 9.82 & 12.55 & 25.98 & 22.74 & 23.39 & 0.83 & 12.52 \\
\hline Total number of tillers & $7.98 \pm 0.11$ & 3.62 & 11.29 & 11.15 & 23.55 & 20.70 & 22.74 & 0.88 & 11.03 \\
\hline Filled grains & $145 \pm 3.01$ & 89.00 & 341.00 & 21.41 & 29.32 & 20.04 & 53.28 & 46.67 & 32.19 \\
\hline Unfilled grains & $35 \pm 1.64$ & 5.00 & 142.00 & 48.11 & 65.23 & 44.04 & 54.42 & 25.59 & 73.13 \\
\hline Spikelet fertility & $81.08 \pm 0.59$ & 56.40 & 95.19 & 7.02 & 11.46 & 9.05 & 37.56 & 7.19 & 8.87 \\
\hline Thousand grain weight & $22.29 \pm 0.33$ & 12.06 & 32.42 & 16.68 & 19.12 & 9.32 & 76.23 & 6.70 & 30.03 \\
\hline Single plant yield & $11.22 \pm 0.29$ & 4.21 & 23.84 & 27.63 & 36.24 & 23.44 & 58.15 & 4.87 & 43.41 \\
\hline Biomass & $23.35 \pm 0.43$ & 12.22 & 38.25 & 18.76 & 27.30 & 19.82 & 47.30 & 6.21 & 26.61 \\
\hline Harvest index & $47.42 \pm 0.58$ & 25.00 & 69.65 & 11.22 & 19.61 & 16.08 & 32.75 & 6.27 & 13.23 \\
\hline Per day productivity & $27.67 \pm 0.72$ & 11.02 & 59.31 & 27.25 & 36.23 & 23.87 & 56.59 & 11.69 & 42.23 \\
\hline Amylose content & $24.3 \pm 0.22$ & 12.49 & 27.49 & 10.25 & 10.41 & 1.67 & 97.42 & 5.08 & 20.89 \\
\hline Gel consistency & $39.15 \pm 1.23$ & 21.67 & 93.67 & 37.29 & 38.00 & 7.27 & 96.34 & 29.53 & 75.42 \\
\hline Alkali spreading value & $5 \pm 0.10$ & 3.00 & 7.00 & 24.69 & 24.91 & 3.29 & 98.26 & 3.98 & 50.42 \\
\hline Kernel length & $5.34 \pm 0.04$ & 4.44 & 6.69 & 9.36 & 9.83 & 2.90 & 91.30 & 0.99 & 18.49 \\
\hline Kernel breadth & $2.13 \pm 0.02$ & 1.70 & 2.76 & 9.38 & 11.99 & 7.85 & 57.14 & 0.30 & 14.11 \\
\hline Kernel L/B ratio & $2.53 \pm 0.02$ & 1.81 & 3.51 & 8.68 & 12.42 & 8.46 & 53.54 & 0.35 & 13.69 \\
\hline
\end{tabular}


Figure.1. Multiple bar plot showing the genetic variability parameters of yield and yield related traits among 150 genotypes. Note: A: Days to 50\% flowering; B: Days to maturity; C: Plant height; D: Panicle length; E: Productive tillers; F: Total number of tillers; G:

Number of filled grains; H: Number of unfilled grains; I: Spikelet fertility; J: Thousand grain weight; K: Single plant yield; L:

Biomass; M: Harvest index; N: Per day productivity; O: Amylose content; P: Gel consistency; Q: Alkali spreading value; R: Kernel length; S: Kernel breadth; T: Kernel L/B ratio

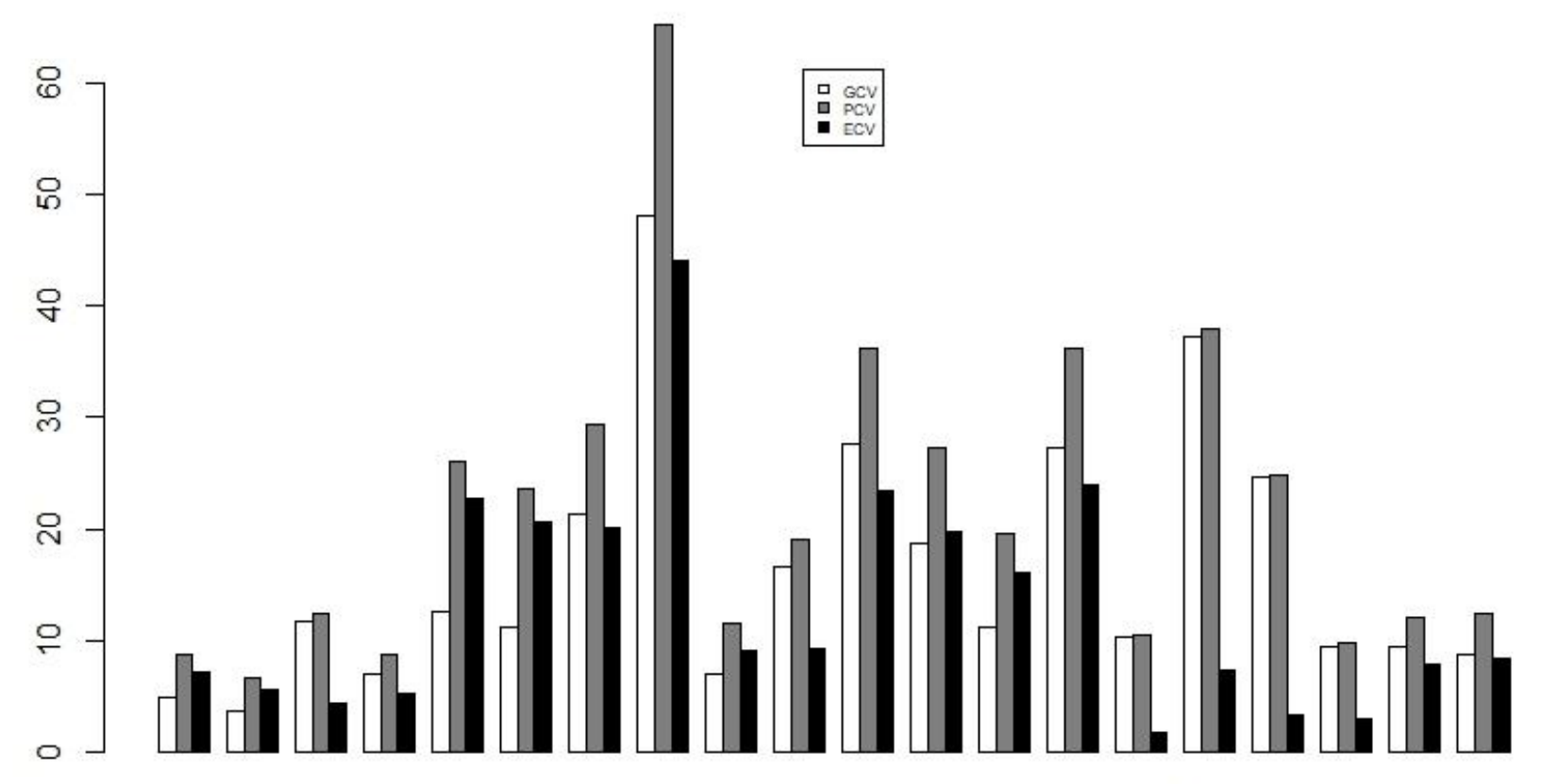

A

C D E F

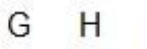

J

K L M N

O P

Q R S T 
Figure.2 Multiple bar plot showing the heritability and genetic advance as per cent of mean of yield and yield related traits among 150 genotypes. Note: A: Days to 50\% flowering; B: Days to maturity; C: Plant height; D: Panicle length; E: Productive tillers; F: Total number of tillers; G: Number of filled grains; H: Number of unfilled grains; I: Spikelet fertility; J: Thousand grain weight; K: Single plant yield; L: Biomass; M: Harvest index; N: Per day productivity; O: Amylose content; P: Gel consistency; Q: Alkali spreading value; R: Kernel length; S: Kernel breadth ; T: Kernel L/B ratio

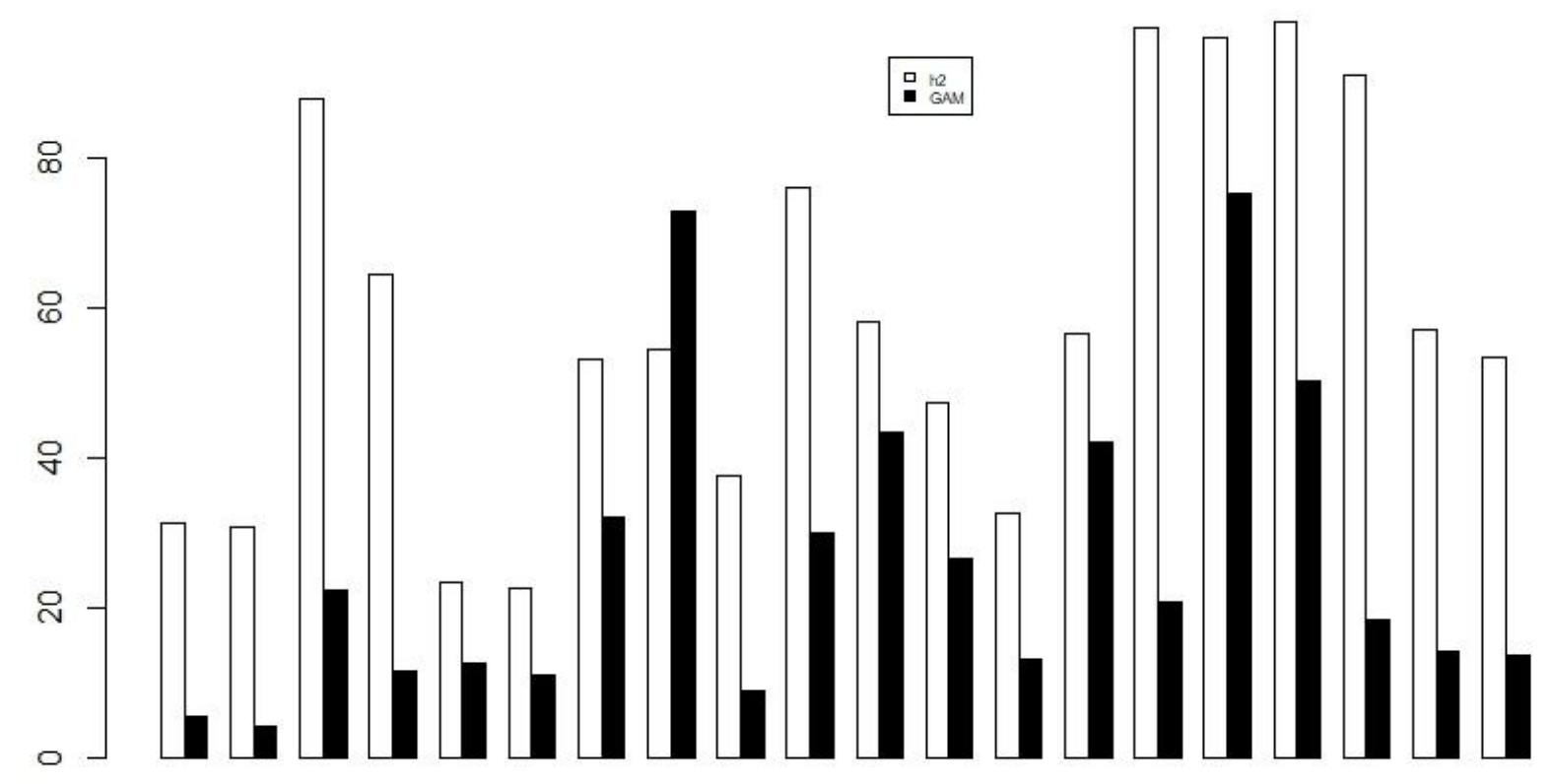

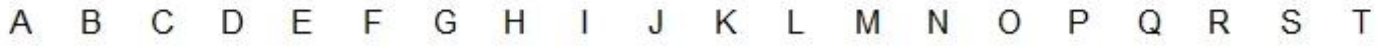


Similar results were reported by Umarani et al., (2017), Sarma et al., (2018), Singh and Verma (2018), Sandeep et al., (2018), Govindaraj et al., (2018) and Asem et al., (2019) for plant height, Thippeswamy et al., (2016), Lakshmi et al., (2017), Sandeep et al., (2018) and Saha et al., (2019) for thousand grain weight, Babu et al., (2012) and Danwani et al., (2013) for gel consistency. High heritability and moderate genetic advance recorded by panicle length and kernel length, filled and unfilled grains, single plant yield, per day productivity, biomass, harvest index, kernel length and kernel L/B ratio which revealed that these characters governed by additive gene action selection may be effective for improvement of these traits. Low heritability and moderate genetic advance was observed for productive and total number of tillers. Moderate heritability and low genetic advance was observed for days to $50 \%$ flowering, days to maturity and for spikelet fertility, which indicates presence of non additive gene action and improvement through selection of such traits may not be rewarding and these can be improved by heterosis breeding. Thippeswamy et al., (2016) reported moderate heritability and low genetic advance for spikelet fertility.

Breeder interest is always for heritable genetic variation while operating selections. Genetic coefficient of variation does not represent heritable genetic variation, this could be established from broad sence heritability calculated from total genetic variance which includes both additive and non additive components of gene action whereas narrow sense heritability which includes heritable genetic variation that is due to additive type gene action. The traits which are showing high variability may not show high heritability and high genetic advance. High variability of a trait may be because of environmental effect. In the present study gel consistency and alkali spreading value which showed high variability expressed high heritability and high genetic advance. This may be because of additive type of gene action governing the expression of these traits. The other traits with high variability are filled and unfilled grains, single plant yield, per day productivity manifested with moderate heritability and high genetic advance. Moderate heritability is being exhibited by moderate effect of environment on phenotypic performance of these traits.

The present genetic variability, heritability and genetic advance studies will be highly helpful for future breeding programmes to predict genetic gain. If crosses made between superior genotypes for further improvement of indica tropical japonica derived lines and selections will be operating in segregating generations by giving importance for plant height and thousand grain weight among yield related traits and amylose content, gel consistency and alkali spreading value among quality traits as these traits governed by additive type of gene action with high heritability coupled with high genetic advance. The traits namely, days to $50 \%$ flowering, days to maturity, spikelet fertility, productive tillers and total number of tillers were under high environmental influence in the present set of experimental material.

\section{References}

"World Rice Statistics." International Rice Research Institute, irri.org/world-ricestatistics.

Abebe, T., Alamerew, S and Tulu, L. 2017. Genetic variability, heritability and genetic advance for yield and its related traits in rainfed lowland rice (Oryza sativa L.) genotypes at Fogera and Pawe, Ethiopia. Advances in Crop Science and Technology. 5(2):1-8.

Asante, M. D., Adjah, K. L Annan-Afful, E. 2019.Assessment of Genetic Diversity 
for Grain Yield and Yield Component Traits in Some Genotypes of Rice (Oryza sativa L.). Journal of Crop Science and Biotechnology. 22(2): 123130.

Asem, I.D., Nongthombam, A., Shaheen, K., Heisnam, N.D., Yurembam, R., Asem, R., Devi, L.Y., Khunjamayum, R., Chanu, T.P., Mukherjee, S., Singh, E.S and Ningthoujam, D.S. 2019. Phenotypic characterization, genetic variability and correlation studies among ten Chakhao (scented) rice of Manipur. International Journal of Current Microbiology and Applied Sciences.8 (2): 612-618.

Babu, R.V., Shreya, K., Dangi, K.S., Usharani, G and Nagesh, P. 2012. Genetic variability studies for qualitative and quantitative traits in popular rice (Oryza sativa L.) hybrids of India. International Journal of Scientific and Research Publications. 2 (6): $1-5$.

Burton, G.W and Devane, E.H. 1952. "Estimating heritability in tall fescue (Festuca arundinaceae) from replicated clonal material," Agronomy Journal, 1952, 45: 478-481.

Dhanwani, R.K., Sarawgi, A.K., Solanki, A and Tiwari, J.K. 2013.Genetic variability analysis for various yield attributing and quality traits in rice (Oryza sativa L.). The Bioscan. 8 (4): 1403-1407.

Dhurai, S.Y., Bhati, P.K and Saroj, S.K. 2014. Studies on genetic variability for yield and quality characters in rice (Oryza sativa L.) under integrated fertilizer management. The Bioscan. 9 (2): 845-848.

FAO 2009. How to Feed the World in 2050. Rome, Italy, Food and Agriculture Organization.

Gokulakrishnan, J., Kumar, B.S and Prakash, M. 2014. Variability studies for some yield and quality traits in rice (Oryza sativa L.). Plant Archives. 14 (1): 533536.

Govintharaj, P., Manonmani, S and Robin, S. 2018. Variability and genetic diversity study in an advanced segregating population of rice with bacterial blight resistance genes introgressed. Ciência e Agrotecnologia. 42(3): 291-296.

Hill, W. G., Goddard, M. E and Visscher, P. M. 2008. Data and theory point to mainly additive genetic variance for complex traits. PLoS genetics. 4(2).110.

IRRI (2013) Standard Evaluation System (SES) for Rice, 5thEdn. Philippines: IRRI

Johnson, H.W., Robinson H.F and Comstock, R.E. Estimation of genetic and environmental variability in soybean. Agronomy Journal, 1955, 47: 314-318.

Lakshmi, L., Rao, B.M.N., Raju, S. Ch. and S. Reddy, N.S. 2017. Variability, correlation and path analysis in advanced generation of aromatic rice. International Journal of Current Microbiology and Applied Sciences.6 (7): 1798-1806.

Lush, J.L., "Intra-sire correlation and regression of offspring in rams as a method of estimating heritability of characters," Proceedings of American Society of Animal Product, 1940, 33: 292-301.

Manjunatha, B., Krishnappa, M and Kumara, N. B. 2017. Genetic variability studies in rice (Oryza sativa L.) genotypes. Trends in Biosciences. 10(38): 80278028.

Peng, S., Laza, R. C., Visperas, R. M., Khush, G. S., Virk, P and Zhu, D. 2004. Rice: progress in breaking the yield ceiling "New directions for a diverse planet". In: Proceedings of the $4^{\text {th }}$ International Crop Science Congress. Brisbane, Australia. 26. 
Saha S.R., Hassan, L., Haque, Md. A., Islam, M.M and Rasel, Md.2019. Genetic variability, heritability, correlation and path analyses of yield components in traditional rice (Oryza sativa L.) landraces. Journal of Bangladesh Agricultural University. 17(1): 26-32.

Sahu, P.K., Sharma, D, Mondal, S., Kumar, V., Singh, S., Baghel, S., Tiwari, A., Vishwakarma, G and Das, B.K. 2017. Genetic variability for grain quality traits in indigenous rice landraces of Chhattisgarh, India. Journal of Experimental Biology and Agricultural Sciences. 5(4):440-455.

Sandeep, S., Sujatha, M., Subbarao, L.V and Neeraja, C.N. 2018. Genetic variability, heritability and genetic advance studies in rice (Oryza sativa L.). International Journal of Current Microbiology and Applied Sciences. 7(12): 3719-3727. doi: https://doi.org/10.20546/ijcmas. 2018.712.424

Sarma, S., Pooja, A.S., Santhosh, D.B., Swamy, V.K.H.V and Shashidhar, H.E. 2018. Genetic variability, heritability and genetic advance for zinc concentration and yield related traits of genotypes of rice (Oryza sativa L.) grown under aerobic condition. International Journal of Pure and Applied Bioscience.6 (4): 347-352.

Singh, N and Verma, O.P. 2018. Genetic variability, heritability and genetic advance in rice (Oryza sativa L.) under salt stressed soil. Journal of Pharmacognosy and Phytochemistry. 7(3): 3114-3117.

Singh, N and Verma, O.P. 2018. Genetic variability, heritability and genetic advance in rice (Oryza sativa L.) under salt stressed soil. Journal of Pharmacognosy and Phytochemistry. 7(3): 3114-3117.

Team RDC.R: A language and environment for statistical computing. $\mathrm{R}$ foundation for statistical computing: Vienna, Austria. Technical Report. Jan 2012.

Thippeswamy, S., Mohan, C.Y., Srinivas, B and Padmaja, D. 2016.Selection of diverse parental lines for heterotic hybrid development in rice (Oryza sativa L.). SABRAO Journal of Breeding and Genetics.48 (3): 285-294.

Tiwari, D. N., Tripathi, S. R., Tripathi, M. P., Khatri, N and Bastola, B. R. 2019. Genetic variability and correlation coefficients of major traits in early maturing rice under rainfed lowland environments of Nepal. Advances in Agriculture. Pp. 1-9.

Umarani, E., Radhika, K., Padma, V and Subbarao, L.V. 2017. Variability, heritability and genetic advance for agro-morphological and grain quality parameters in landraces of rice (Oryza sativa L.). Environment and Ecology. 35 (3): 1682-1687.

\section{How to cite this article:}

Sruthi, K., K. B. Eswari, A. S. Hari Prasad, Ch. Damodhar Raju, M. Sheshu Madhav and Dhandapani, A. 2020. Assessment of Genetic Variability, Heritability and Genetic Advance for Yield and Quality Traits in Indica Tropical Japonica Derived Lines. Int.J.Curr.Microbiol.App.Sci. 9(04): 2971-2981. doi: https://doi.org/10.20546/ijcmas.2020.904.348 